\title{
Iron metabolism in the veal calf. The availability of different iron compounds*
}

\author{
By I. BREMNER AND A. C. DALGARNO \\ Rowett Research Institute, Bucksburn, Aberdeen, $A B 29 S B$ \\ (Received 21 April 1972-Accepted 9 August 1972)
}

\begin{abstract}
I. The haematological status of Ayrshire bull calves reared on fat-supplemented skim milk from about $17 \mathrm{~d}$ of age has been examined. The calves were moderately anaemic after an I I-week experiment and it was shown that their performance was related to their blood haemoglobin concentration.

2. The relative availabilities of iron from $\mathrm{FeSO}_{4}$, ferric citrate, ferric-ethylenediaminetetraacetate and iron phytate were compared at a supplementary dietary concentration of $30 \mu \mathrm{g} \mathrm{Fe} / \mathrm{g}$. No significant differences were noted between the three soluble Fe sources but the Fe of the insoluble iton phytate was less available.

3. The decreases in blood haemoglobin concentrations in all calves were greatest in the early weeks of the experiment. In calves given supplementary $\mathrm{Fe}$, however, there was generally an improvement in haematological status after 6 weeks. Plasma Fe concentrations fell to $0.20 \mu \mathrm{g} / \mathrm{ml}$ in the most deficient animals. Total Fe binding capacities averaged about Io $\mu \mathrm{g} \mathrm{Fe} / \mathrm{ml}$ in the later stages of the expcriment.

4. Some of the calves were copper-deficient, and in some animals the effects of dietary $\mathrm{Cu}$ supplementation on both $\mathrm{Cu}$ and Fe metabolism were studied. About $50 \%$ of the supplementary $\mathrm{Cu}$ was retained in the livers of the calves.

5. A dietary intake of $40 \mu \mathrm{g} \mathrm{Fe} / \mathrm{g}$ milk powder appears to be sufficicnt to prevent all but a very mild anaemia, provided the $\mathrm{Fe}$ is presented in solubie form.
\end{abstract}

In the Brambell Report (Brambell, I965) it was recommended that in the intensive production of veal calves 'the diet should be such as to ensure normal levels of haemoglobin ...' and that 'the diet should be so reinforced with iron in a suitable form as to ensure that on a normal intake the animal is in no wise deficient in this element'. Implementation of these recommendations has been complicated by the absence of knowledge of what constitutes 'normal' haemoglobin (Hb) levels, of what constitutes a 'suitable' form of $\mathrm{Fe}$ and of the criteria by which a state of deficiency should be assessed.

The rearing of young calves for veal solely on milk-based rations can result in the development of a state of anaemia. The anaemia can be readily prevented by supplementing the ration with $\mathrm{Fe}$, given by mouth or parenterally, and some assessment has been made in the past of the Fe requirements of such calves (Blaxter, Sharman \& MacDonald, 1957; Matrone, Conley, Wise \& Waugh, 1957; Roy, Gaston, Shillam, Thompson, Stobo \& Greatorex, I964). Most of these assessments have been made on calves maintained on whole milk, and it is uncertain how applicable these estimates are to present commercial practice where the diets generally consist of fatsupplemented skim-milk preparations. Such diets generally produce greater weight gains than whole milk in calves and therefore the absolute requirements for Fe will also be greater (Roy et al. 1964).

* A preliminary report of this work was published in Proc. Nutr. Soc. (1972), 31, 75A. 
Table I. Composition of milk-substitute powder $(\mathrm{g} / \mathrm{kg})$

$\begin{array}{lr}\text { Oil } & 240 \\ \text { Protein } & 265 \\ \text { Fibre } & 0 \\ \text { Ash } & 70\end{array}$

Supplements

Vitamin A ( $\mu \mathrm{g}$ retinol equivalent/kg)

Cholecalciferol $(\mu \mathrm{g} / \mathrm{kg})$

4800

Vitamin $\mathrm{E}(\mathrm{mg} \alpha$-tocopherol equivalent $/ \mathrm{kg})$

Thiamin $(\mathrm{mg} / \mathrm{kg})$

Riboflavin ( $\mathrm{mg} / \mathrm{kg}$ )

Pyridoxine ( $\mathrm{mg} / \mathrm{kg}$ )

Pantothenic acid ( $\mathrm{mg} / \mathrm{kg})$

Nicotinic acid ( $\mathrm{mg} / \mathrm{kg})$

Ascorbic acid ( $\mathrm{mg} / \mathrm{kg}$ )

Cyanocobalamin $(\mu \mathrm{g} / \mathrm{kg})$

Magnesium $(\mathrm{mg} / \mathrm{kg})$

Manganese (mg/kg)

Zine (mg/kg)

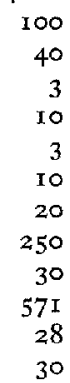

In this paper, the availability of various $\mathrm{Fe}$ sources to calves maintained under conditions resembling those in commercial practice is assessed by comparison of the haematological status and tissue $\mathrm{Fe}$ concentrations of the animals. In addition, as commercial milk preparations frequently contain no supplementary copper, the $\mathrm{Cu}$ status of the calves was determined. In some animals the effects on both $\mathrm{Cu}$ and $\mathrm{Fe}$ metabolism of supplementation of the ration with $\mathrm{Cu}$ was examined.

\section{EXPERIMENTAL}

\section{Diets and supplements}

The diet, obtained by spray-drying an emulsion of skim milk and fat, was manufactured to specification by Volac Ltd (Wendy, Royston, Herts.). The composition of the diet is described in Table $\mathrm{I}$. The Fe and $\mathrm{Cu}$ contents of the milk powder were found to be 9.8 and $0.8 \mu \mathrm{g} / \mathrm{g}$ respectively. The milk powder was reconstituted with deionized water at $37^{\circ}$. The feed intake of the calves at the start was $284 \mathrm{~g}$ milk powder/feed. This was increased by about $5_{5} 6 \mathrm{~g} / \mathrm{feed}$ twice each week so that the final feed intake was $1535 \mathrm{~g} /$ feed. The concentration of solids in the milk was $120 \mathrm{~g} / 1$ initially and was increased by about $6 \mathrm{~g} / \mathrm{l}$ every week over the first 6 weeks until it was $177 \mathrm{~g} / 1$. It was kept at this figure after that. The calves were fed twice a day, from plastic buckets.

The diet was supplemented with one of four Fe compounds: $\mathrm{FeSO}_{4}$, ferric citrate, ferric-ethylenediaminetetra-acetate (Fe-EDTA) (provided by ABM Industrial Products Ltd, Stockport, Cheshire) and iron phytate. The iron phytate was prepared from aqueous solutions of $\mathrm{FeSO}_{4}$ and sodium phytate ( $\mathrm{Na}$ salt of inositol hexaphosphoric acid). The resultant precipitate was collected by centrifugation, washed with water and ethanol, and then dried under reduced pressure at $40^{\circ}$. The Fe content was $177 \mathrm{~g} / \mathrm{kg}$. 
The Fe compounds were dissolved (or dispersed, for iron phytate) in distilled water and were added to the reconstituted milk at a level of $30 \mu \mathrm{g} \mathrm{Fe} / \mathrm{g}$ dry powder, making the total concentration $40 \mu \mathrm{g} \mathrm{Fe} / \mathrm{g}$ dry powder. In some instances the milk was further supplemented by the addition of $\mathrm{I}_{5} \mathrm{mg} \mathrm{Cu}$ (as an aqueous solution of $\mathrm{CuSO}_{4}$ ) per feed.

\section{Experimental design}

The experiment was of a randomized block design and consisted of five treatments in each of four blocks of calves. The treatments were:

$\begin{array}{cl}\text { Treatment } & \text { Fe supplement } \\ \text { I } & \text { None } \\ 2 & \text { FeSO }_{4} \\ 3 & \text { Ferric citrate } \\ 4 & \text { Fe-EDTA } \\ 5 & \text { Iron phytate }\end{array}$

It was realized during the experiment that the diet being used was low in $\mathrm{Cu}$; consequently one calf in each treatment group was given the $\mathrm{Cu}$ supplement from the beginning of week 7 onwards ( $c .53 \mathrm{~d}$ of age). The calves were kept on experiment for II weeks.

\section{Calves}

The Ayrshire bull calves were bought from farms in the neighbourhood of Aberdeen at about $5 \mathrm{~d}$ of age. 'They had all received colostrum and were maintained on unsupplemented whole milk until the start of the experiment, when they were generally about $7 \mathrm{~d}$ old. They were then housed in a heated, well-ventilated building in wooden pens, fitted with slatted floors. The small amount of external metal in the pens was covered with polyurethane paint.

The calves were weighed weekly. In the event of severe diarrhoca or of excessive food refusals the food intake was reduced for a short period until the faeces were normal or the appetite was restored. If this had no effect the animals were dosed with sulphadimidine ( $14 \mathrm{~g}$ ) and streptomycin $(0.7 \mathrm{~g})$ over $3 \mathrm{~d}$.

Blood samples were collected, fortnightly or, in some instances, weekly, into acidwashed heparinized tubes from the jugular veins of the calves at about $2 \mathrm{~h}$ after the morning feed.

\section{Analytical methods}

Plasma Fe concentrations were determined by the automated colorimetric method of Young \& Hicks (1965). Total Fe-binding capacities were determined by the method of Birdsall, Kok \& Wild ( 1965 ), except that the amount of ionic Fe added to the plasma was double the recommended quantities and the final Fe analyses were by the above method. Blood $\mathrm{Cu}$ concentrations were measured by atomic absorption spectroscopy after deproteinization by precipitation with an equal volume of $100 \mathrm{~g}$ trichloroacetic acid/1. Ceruloplasmin levels were determined by the method of Houchin (1958), using the standardization procedure of Rice (1962).

$\mathrm{Fe}$ and $\mathrm{Cu}$ concentrations in freeze-dried tissues were determined after digestion with $\mathrm{HNO}_{3}-\mathrm{HClO}_{4}-\mathrm{H}_{2} \mathrm{SO}_{4}$ by the method of Young \& Hicks ( $\left.{ }_{9} 65\right)$ and by atomic 
Table 2. Effect of different iron supplements on performance of calves over an I I-week period on treatments $\mathrm{I}-5$

(Mean values for four calves/treatment)

\begin{tabular}{|c|c|c|c|c|c|}
\hline $\begin{array}{c}\text { Treatment } \\
\text { No. }\end{array}$ & Supplement & $\begin{array}{c}\text { Initial } \\
\mathrm{wt} \\
(\mathrm{kg})\end{array}$ & $\begin{array}{l}\text { Weight } \\
\text { gain } \\
(\mathrm{kg})\end{array}$ & $\begin{array}{c}\text { Feed* } \\
\text { intake } \\
(\mathrm{kg})\end{array}$ & $\begin{array}{l}\text { Feed conversion ratio } \\
\text { (kg milk powder intake } \\
\text { kg weight gain) }\end{array}$ \\
\hline I & None & $43 \cdot 8$ & $85 \cdot 8$ & $130 \cdot 3$ & $I \cdot 52$ \\
\hline 2 & $\mathrm{FeSO}_{4}$ & $38-8$ & 87.5 & $126 \cdot I$ & $1 \cdot 45$ \\
\hline 3 & Ferric citrate & $37 \cdot 3$ & 87.5 & 130.4 & I 49 \\
\hline 4 & Fe-EDTA & $4 x \cdot 4$ & $9 \mathbf{I} \cdot 6$ & $135^{\circ} \mathrm{I}$ & I. 48 \\
\hline 5 & Iron phytate & $38 \cdot 6$ & 85.0 & $123 \cdot 6$ & $I \cdot 46$ \\
\hline $\begin{array}{l}\text { SE of difference } \\
\text { between means }\end{array}$ & 一 & - & $6 \cdot 8$ & $5 \cdot 9$ & 0.064 \\
\hline
\end{tabular}

absorption spectroscopy respectively. Storage of $\mathrm{Fe}$ in liver was measured by the method of Drysdale \& Ramsay (1965).

Statistical analysis of results was by analysis of variance unless otherwise indicated.

RESULTS

\section{Live-weight gain and efficiency of food conversion}

The effects on live-weight gain and feed conversion ratio of supplementing the milk with the various Fe compounds are shown in Table 2 . There were no significant differences between the different treatments. The performance of the animals, with an average weight gain of $I \cdot 14 \mathrm{~kg} / \mathrm{d}$, was probably fairly typical for Ayrshire calves maintained for veal production. The calves usually consumed almost all the milk offered and total milk consumption over I I weeks varied between 127 and $140 \mathrm{~kg}$. Some calves suffered from anorexia throughout the experiment (two calves consumed less than I Io kg milk) and in most calves food intake was more irregular towards the end of the experiment. Food intake was not significantly related to dietary treatment, although there was a possible positive trend in its relationship with blood $\mathrm{Hb}$ concentration.

The performance of the calves was related to their final blood $\mathrm{Hb}$ concentrations. The combined relationships for all calves, on all treatments, were expressed by the following regression equations, with the SE of the regression coefficient in parentheses:

$$
Y=0.826+0.0039 x\left( \pm 0.01_{4}\right),
$$

where $\quad Y=$ weight gain $(\mathrm{kg} / \mathrm{d})$ and $x=$ Hb concentration $(\mathrm{g} / \mathrm{l})$;

and $\quad Z=\mathrm{I} \cdot 70-0.00269 x( \pm 0.01 \mathrm{I} 5)$

where $\quad Z=$ feed conversion ratio and $x=$ Hb concentration $(\mathrm{g} / 1)$.

\section{Haematological measurements}

The changes in $\mathrm{Hb}$ concentration and packed cell volume (PCV) over the experimental period are shown in Fig. I for the control calves, those given soluble Fe salts 

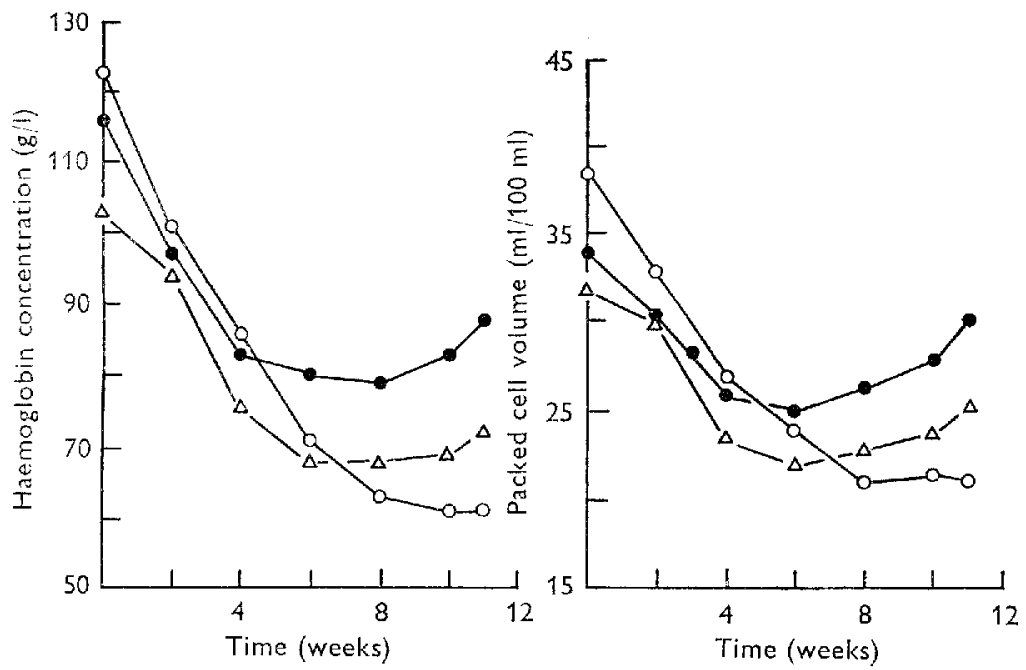

Fig. I. Changes in blood haemoglobin concentrations and packed cell volumes during the experiment for control calves (O), for those given soluble iron ( $)$ and for those given iron phytate $(\triangle)$.

and those given iron phytate. With all treatments there was a fairly rapid fall in $\mathrm{Hb}$ concentrations for about 6-8 weeks, following which the $\mathrm{Hb}$ concentrations in the calves given soluble salts increased to a final mean value of $88 \mathrm{~g} / \mathrm{l}$. Hb concentrations increased by only $4 \mathrm{~g} / \mathrm{l}$ in calves given iron phytate and decreased by only a further $2 \mathrm{~g} / \mathrm{l}$ in the control calves.

When allowance was made by covariance techniques for the greater initial $\mathrm{Hb}$ concentrations in the control calves, there were significant differences $(P<0.05)$ in the $\mathrm{Hb}$ concentrations in the control and Fe-supplemented calves within two weeks (Table 3). The magnitude and statistical significance of these differences increased as the experiment proceeded. There were also differences in the apparent availability of the various $\mathrm{Fe}$ supplements. $\mathrm{Hb}$ concentrations in calves given $\mathrm{Fe}-\mathrm{EDTA}$ were significantly greater $(P<0.05)$ than those in other calves at weeks 4 and 6 , whereas in calves given iron phytate the concentrations were significantly less $(P<0.05$ and $<0.01)$ than in other supplemented calves from week 6 onwards.

The effects of treatment on PCV were generally similar to those on $\mathrm{Hb}$ concentration (Table 3 and Fig. I). From week 8 onwards PCV was significantly least in the control calves and from week ro onwards PCV in the calves given iron phytate was significantly less than in other Fe-supplemented calves.

Although there was a general decrease in erythrocyte count, mean corpuscular volume and mean corpuscular $\mathrm{Hb}$ concentration over the experimental period (Table 3), there were no statistically significant differences between treatments in the final values attained. The decreases during the experimental period in erythrocyte count over all treatments from 9.17 to $7.86\left(\mathrm{IO}^{-6} / \mathrm{mm}^{3}\right)(\mathrm{SE} \pm 0.44)(P<0.0 \mathrm{I})$ and in mean corpuscular $\mathrm{Hb}$ concentration from 319 to $292 \mathrm{~g} / 1$ (SE \pm 10.3$)(P<0.05)$ were significant, whereas the decrease in mean corpuscular volume from 38.3 to $34.9 \mu \mathrm{m}^{3}$ (SE \pm 


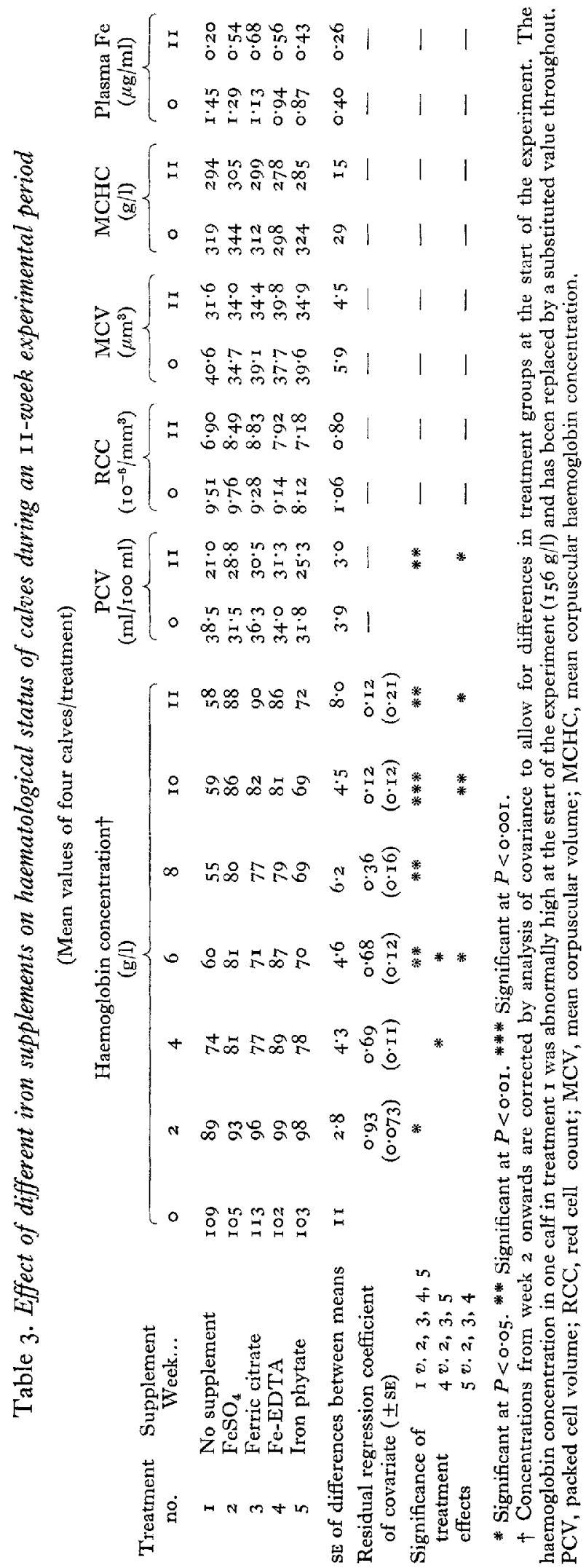




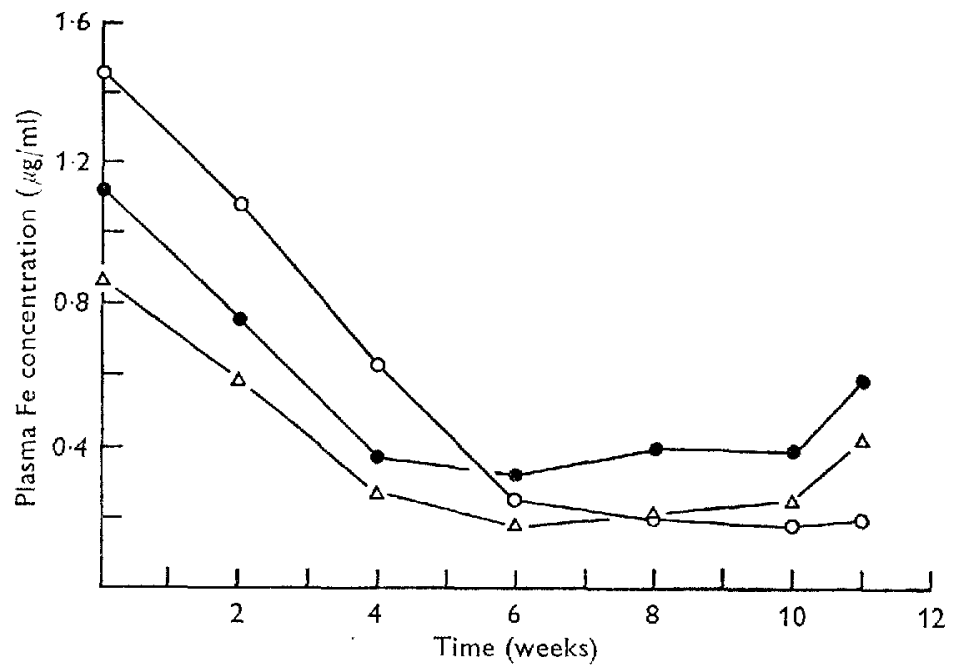

Fig. 2. Changes in plasma iron concentration during the experiment for control calves (O), for those given soluble $\mathrm{Fe}(\bullet)$ and for those given iron phytate $(\Delta)$.

Table 4. Effects of different iron supplements on tissue Fe and spleen copper concentrations ( $\mu g / g$ dry matter) in calves on treatments $\mathrm{I}-5$

(Mean values for four calves/treatment)

\begin{tabular}{|c|c|c|c|c|c|c|c|}
\hline $\begin{array}{c}\text { Treatment } \\
\text { no. }\end{array}$ & Supplement & Liver & $\begin{array}{c}\text { Liver } \\
\text { (non-haem } \\
\text { Fe) }\end{array}$ & Spleen & Kidney & Muscle & $\begin{array}{l}\text { Spleen } \\
\mathrm{Cu}\end{array}$ \\
\hline 1 & No supplement & $59 \cdot 7$ & $24^{*} 9$ & 309 & $64^{\prime} 9$ & $\mathrm{I} 2 \cdot 2$ & $5 \cdot 89$ \\
\hline 2 & $\mathrm{FeSO}_{4}$ & 557 & 19.5 & 238 & 100.8 & $\mathrm{I} 8 \cdot \mathrm{I}$ & $4 \cdot 27$ \\
\hline 3 & Ferric citrate & $54 \cdot 3$ & $2 \mathrm{r} \cdot 8$ & 274 & $8_{3} \cdot 6$ & $19 \cdot 6$ & $4 \cdot 98$ \\
\hline 4 & Fe-EDTA & $58 \cdot 0$ & $19^{\circ} 9$ & 289 & $72 \cdot 9$ & $17 \cdot 6$ & $5 \cdot 86$ \\
\hline 5 & Iron phytate & $52 \cdot 0$ & $2 I \cdot 9$ & 256 & $62 \cdot 7$ & 14.5 & $3 \cdot 99$ \\
\hline $\begin{array}{l}\mathrm{SE} \text { of difference } \\
\text { between means }\end{array}$ & - & $5 \cdot 9$ & $2 \cdot 0$ & $77 \dagger$ & 10.4 & 4.17 & 0.59 \\
\hline $\begin{array}{l}\text { Significance of } \\
\text { differences } \\
\text { between } \\
\text { treatments } \\
\text { I } v .2,3,4,5\end{array}$ & $一$ & 一 & * & - & 一 & 一 & * \\
\hline $\begin{array}{r}* \text { Significant a } \\
+ \text { Approximate } \\
\text { ubstituted value, } \\
+ \text { Only three }\end{array}$ & $\begin{array}{l}\text { at } P<0.05 \\
\text { e value only. Onc } \\
\text { obtained by stat } \\
\text { calves/treatment. }\end{array}$ & $\begin{array}{l}\text { alf } \mathrm{i} \\
\text { ical }\end{array}$ & men & 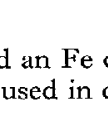 & 1 & I 213 & 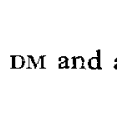 \\
\hline
\end{tabular}

2.29) was not. Plasma Fe concentrations were greatly reduced over the experimental period; values initially averaged $\mathrm{I} \cdot 4 \mu \mathrm{g} \mathrm{Fe} / \mathrm{ml}$ but fell rapidly (Fig. 2), minimum values for the different treatments being attained usually within 6 weeks. No significant differences were noted between treatments, although the control calves generally had the lowest average concentrations $(0 \cdot 2 \mu \mathrm{g} / \mathrm{ml})$ over much of the experimental period. Measurements of total Fe-binding capacity were made at the beginning and again in the later stage of the experiment; no significant differences between treatments 
Table 5. Effects of a dietary $\mathrm{Cu}$ treatment on tissue Fe concentrations in calves

\begin{tabular}{|c|c|c|c|c|c|c|c|}
\hline \multirow[b]{2}{*}{ Treatment } & \multirow[b]{2}{*}{$\begin{array}{l}\text { No. of } \\
\text { calves }\end{array}$} & \multirow[b]{2}{*}{$\begin{array}{c}\text { Liver } \\
\text { dry matter } \\
(\mathrm{g} / \mathrm{kg})\end{array}$} & \multicolumn{5}{|c|}{ Tissue $\mathrm{Fe}(\mu \mathrm{g} / \mathrm{g}$ dry matter) } \\
\hline & & & Liver & $\begin{array}{c}\text { Liver } \\
(\text { non-haem } \mathrm{Fe})\end{array}$ & Kidney & Spleen & Muscle \\
\hline $\begin{array}{l}\text { No } \mathrm{Cu} \\
\quad \text { supplement }\end{array}$ & 15 & 277 & $56 \cdot 7$ & $23 \cdot 7$ & $78 \cdot 7$ & 258 & $22 \cdot 3$ \\
\hline$+\mathrm{Cu}$ & 5 & $3 \times 5$ & $53 \cdot 7$ & 15.4 & $72-6$ & 318 & $23 \cdot 3$ \\
\hline $\begin{array}{l}\text { SE of differences } \\
\text { between means }\end{array}$ & 一 & $7 \cdot 5$ & $5 * 3$ & $\mathbf{r} \cdot 8$ & $9 \cdot 3$ & 77 & $3 \cdot 2 \uparrow$ \\
\hline $\begin{array}{l}\text { Significance } \\
\text { of differences }\end{array}$ & - & $* * *$ & - & ceiving no & pple & - & - \\
\hline
\end{tabular}

were noted. Average values $( \pm \mathrm{SD})$ at weeks Io and II were $9 \cdot 46 \pm$ I.3I and 10.24 \pm $0.88 \mu \mathrm{g} \mathrm{Fe} / \mathrm{ml}$ respectively, compared with the mean initial values of $5.77 \pm 0.49 \mu \mathrm{g}$ $\mathrm{Fe} / \mathrm{ml}$.

\section{Tissue concentrations of $\mathrm{Fe}$}

The mean concentrations of $\mathrm{Fe}$ in liver, spleen, kidney and muscle for the different treatments are shown in Table 4. No treatment effects were evident in most instances, but the storage $\mathrm{Fe}$ reserves in the livers of the control calves were paradoxically greater than for the other calves $(P<0.05)$. There were no treatment effects on the dry matter (DM) content or total weight of the tissues.

\section{Effects of $\mathrm{Cu}$ supplement on $\mathrm{Fe}$ and $\mathrm{Cu}$ concentrations in tissues}

In Table 5 the effect of adding a daily supplement of $30 \mathrm{mg} \mathrm{Cu}\left(\right.$ as $\mathrm{CuSO}_{a}$ ) to the rations of one calf from each treatment from week 7 onwards are shown. There was a very highly significant reduction in the concentrations of non-haem $\mathrm{Fe}$ in the liver of the $\mathrm{Cu}$-supplemented calves $(P<0 \cdot 00 \mathrm{r})$, but no change in other tissues. There was also an increase in the liver DM content in the supplemented calves $(P<0.001)$. The $\mathrm{Cu}$ concentrations in the splcens of calves in Fe treatments $\mathrm{I}$ and 4 were significantly greater $(P<0.05)$ than those in treatments 2 and 5 (Table 4$)$. However, in general, $\mathrm{Fe}$ treatments had no effect on tissue $\mathrm{Cu}$ concentrations; consequently in Tables 6 and 7 the mean results for the combined $\mathrm{Fe}$ treatments are reported.

In these tables the effects of $\mathrm{Cu}$ supplementation on blood $\mathrm{Cu}$, plasma $\mathrm{Fe}$ and ceruloplasmin concentrations and on tissue $\mathrm{Cu}$ concentrations are shown. At no stage in the experiment were mean blood $\mathrm{Cu}$ concentrations indicative of the existence of a stage of hypocupraemia $(<0.6 \mu \mathrm{g} / \mathrm{ml}$; Underwood, 1971), but in five of the calves blood $\mathrm{Cu}$ concentrations were in the range $0.6-0.85 \mu \mathrm{g} \mathrm{Cu} / \mathrm{ml}$ and in these calves the possible development of marginal $\mathrm{Cu}$ deficiency might be suspected. Mean ceruloplasmin concentrations in these calves were 13.5 i.u. $/ 1$, compared with an average of 20.6 i.u. $/ 1$ for all calves which were not given supplementary $\mathrm{Cu}$. The concentrations of $\mathrm{Cu}$ in the livers of calves not given supplementary $\mathrm{Cu}$ were low, the mean value being $25.3 \mu \mathrm{g} / \mathrm{g}$ DM. Indeed, the liver $\mathrm{Cu}$ concentrations in about $50 \%$ of these 
Vol. 29

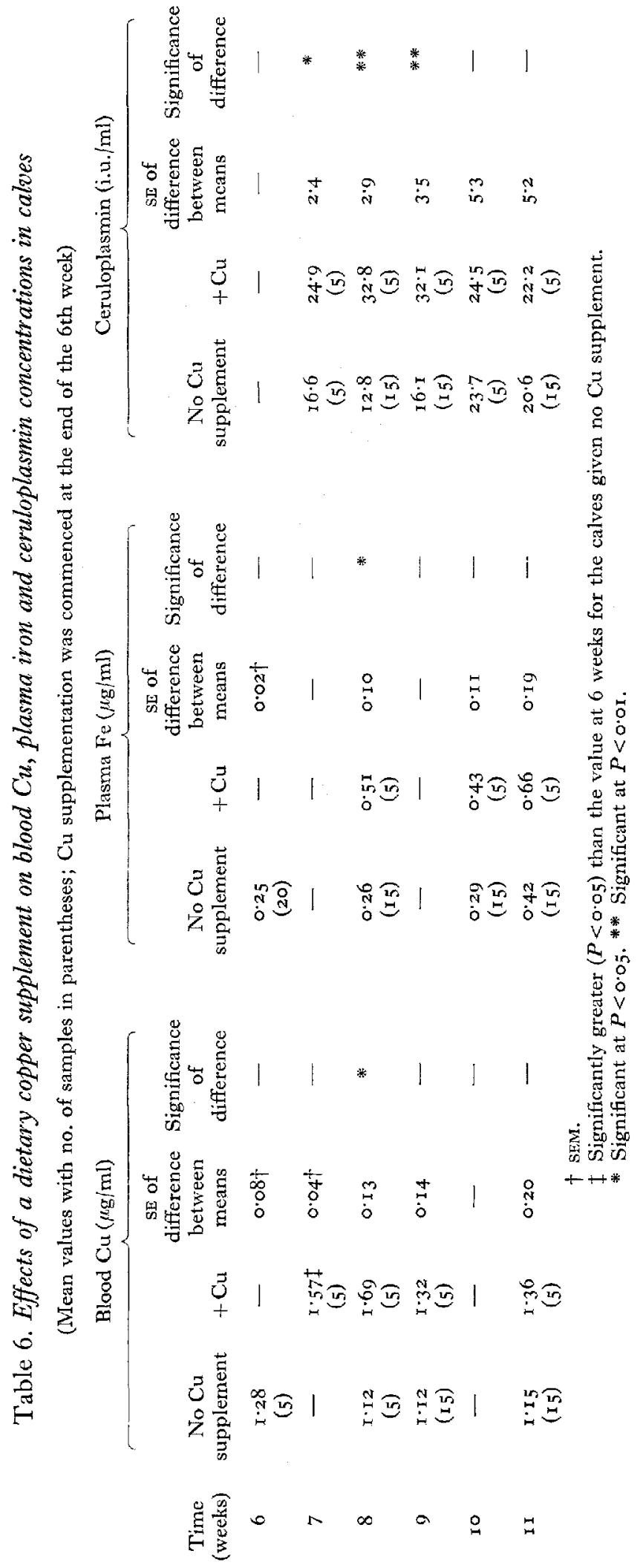


Table 7. Effects of a dietary copper supplement on tissue Cu concentrations ( $\mu g^{\prime} g$ dry matter) in calves

\begin{tabular}{|c|c|c|c|c|c|}
\hline Treatment & No. of calves & Liver & Spleen & Kidney & Muscle \\
\hline No $\mathrm{Cu}$ supplement & I 5 & $25 \cdot 3$ & 4.50 & $19 \cdot 9$ & $2 \cdot 22$ \\
\hline$+\mathrm{Cu}$ & 5 & $45^{2}$ & $6 \cdot 51$ & $26 \cdot 4$ & $2 \cdot 33$ \\
\hline $\mathrm{SE}$ of difference between means & - & $39^{\circ} 5$ & 0.53 & $2 \cdot 7$ & $0.45 t$ \\
\hline Significance of differences & - & $* * *$ & $* * *$ & $* *$ & - \\
\hline
\end{tabular}

animals were $<12.5 \mu \mathrm{g} / \mathrm{g} \mathrm{DM}$ and these animals could therefore be described as $\mathrm{Cu}$-deficient. In Table 6 it can be seen that there were significant effects of dietary $\mathrm{Cu}$ supplementation on blood $\mathrm{Cu}$ and plasma $\mathrm{Fe}$ and ceruloplasmin concentrations. The increases in concentrations were statistically significant only in the period 2-3 weeks after $\mathrm{Cu}$ administration was commenced. The increased dietary intake of $\mathrm{Cu}$ caused a dramatic increase in liver $\mathrm{Cu}$ concentration. The mean value for the $\mathrm{Cu}$-supplemented calves was $452 \mu \mathrm{g} / \mathrm{g}$ DM and it can be calculated from the liver weights of the calves that about $50 \%$ of the supplementary $\mathrm{Cu}$ was retained in the livers of these calves. There were also increases, though less pronounced, in the $\mathrm{Cu}$ concentrations in spleen and kidney $(P<0.001$ and $<0.01$ respectively), but not in muscle.

\section{DISCUSSION}

The experiment has shown that when calves are maintained on rations based upon milk products without supplementary Fe a state of anaemia rapidly develops. Within 2 weeks the calves showed signs of an increased rate of decline in $\mathrm{Hb}$ concentrations, when compared with Fe-supplemented controls. Final concentrations were $6 \mathrm{I} \mathrm{g} / \mathbf{l}$ after I I weeks on experiment and, using the criterion of Holman (1956) for conventionally reared calves, this could be classified as a state of moderate anaemia. The average daily fall in $\mathrm{Hb}$ concentration in control calves over the experimental period was $0.66 \mathrm{~g} / 1$, but most of this fall occurred in the early stage of the experiment. Over the first 6 weeks the average daily fall was $x \cdot I 7$ and over the final 5 weeks $0.057 \mathrm{~g} / \mathrm{l}$.

These average daily falls in $\mathrm{Hb}$ concentration are similar to those reported by Blaxter et al. (1957) $(0.65 \mathrm{~g} / \mathrm{l})$ and Roy et al. ( 1964$)(0.82 \mathrm{~g} / \mathrm{l})$ for calves maintained on whole milk, which generally has an Fe concentration of around $3 \mu \mathrm{g} / \mathrm{g} \mathrm{DM}$, compared with $10 \mu \mathrm{g} \mathrm{Fe} / \mathrm{g}$ in the basal diet used here. However, their calves gained weight over the comparable experimental period at only 0.42 and $0.76 \mathrm{~kg} / \mathrm{d}$, in contrast with the average weight gain of $1 \cdot 14 \mathrm{~kg} / \mathrm{d}$ for the calves in this experiment. It is probable that the apparent anomalies between $\mathrm{Fe}$ intake and change in $\mathrm{Hb}$ concentration in the different studies are associated with the differences in growth rate.

Although the mean weight gains of the calves given supplementary Fe in the form of $\mathrm{FeSO}_{4}$, ferric citrate and $\mathrm{Fe}-\mathrm{EDTA}$ were greater than for the other calves, the differences were not significant. This contrasts with the findings of Eeckhout, Casteels \& Buysse (1969) and of Roy et al. (1964), who reported improved performance in 
calves given supplementary $\mathrm{Fe}$ either orally or by injection. The failure to detect significant differences in performance in the present study is probably a joint consequence of the relatively small number of animals which could be allocated to each treatment and of the large variation in the Fe stores of individual calves at the start of the experiment. $\mathrm{Hb}$ concentrations initially ranged from 82 to $156 \mathrm{~g} / 1$. Roy et al. (1964) have also commented on the large variations in Fe status of calves at birth.

Despite this, it was noted that there was a significant correlation between the weight gain of the calves and the final $\mathrm{Hb}$ concentration and also a significant negative correlation between the feed conversion ratio and final $\mathrm{Hb}$ concentration. Roy et al. claimed that the beneficial effect of supplementary $\mathrm{Fe}$ on weight gain was mainly evident when $\mathrm{Hb}$ concentrations fell below $7 \circ \mathrm{g} / \mathrm{l}$ and that the main nutritional benefit of $\mathrm{Fe}$ was to decrease anorexia. However, the present results did not reveal the existence of a significant correlation between feed intake and $\mathrm{Hb}$ concentration.

When supplementary $\mathrm{Fe}$ was given (at a total $\mathrm{Fe}$ intake of $40 \mu \mathrm{g} / \mathrm{g} \mathrm{DM}$ ), there was still a fall in $\mathrm{Hb}$ concentrations for about 8 weeks. The dietary intake of Fe may have been less than the calves' normal requirement, but nevertheless it is not certain that the fall in $\mathrm{Hb}$ concentration over the first weeks of life is a consequence solely of nutritional insufficiency. A similar phenomenon has been observed in human infants, with a decrease in $\mathrm{Hb}$ concentrations from $\mathrm{I} 80 \mathrm{~g} / \mathrm{l}$ to $\mathrm{I} 20 \mathrm{~g} / \mathrm{l}$ recorded over the first 3-4 months of life (Walsh, Kaldor, Brading \& George, 1955). It is possible that this change is associated with the change from the relatively anoxic intra-uterine conditions and the destruction of foetal $\mathrm{Hb}$. Changes in $\mathrm{Hb}$ concentrations in calves similar to those found here have been reported by several groups of workers, even in calves given apparently adequate supplies of $\mathrm{Fe}$ (Owen, Voelker, Jacobson \& Allen, I955; Wing, Jacobson \& Allen, I955; Eeckhout et al. I969).

Lanz (1956) has reported that plasma Fe concentrations in calves decreased in the period immediately after birth from 1.60 to $0.50 \mu \mathrm{g} \mathrm{Fe} / \mathrm{ml}$ and did not increase until vegetable fodder was consumed, with concomitant increase in dietary Fe intake. Bremner (1966) has claimed, however, that milk-fed calves which had access to dry fodder generally showed a transient increase in plasma $\mathrm{Fe}$ concentrations between I and 3 weeks after birth, normal adult levels of around $\mathrm{I}_{4} 4 \mu \mathrm{g} \mathrm{Fe} / \mathrm{ml}$ being maintained after that. In the present study, which commenced when the calves were 2-3 weeks old, there was a gradual fall in plasma $\mathrm{Fe}$ concentrations in all animals, regardless of Fe intake, from about $I^{\cdot} \cdot I_{4}$ to $0.28 \mu \mathrm{g} / \mathrm{ml}$ over 6 weeks but in animals given supplementary $\mathrm{Fe}$, the values then increased to about $0.55 \mu \mathrm{g} / \mathrm{ml}$. These changes tended to precede the similar changes described earlier in blood $\mathrm{Hb}$ concentrations.

As is usual in $\mathrm{Fe}$-deficiency anaemia the low plasma $\mathrm{Fe}$ concentrations were associated with high plasma total $\mathrm{Fe}$-binding capacities. Initial values were fairly normal at $5 \cdot 77 \pm 0.49 \mu \mathrm{g} \mathrm{Fe} / \mathrm{ml}$ but at the end of the experiment they had risen to the exceptionally high value of over ro $\mu \mathrm{g} \mathrm{Fe} / \mathrm{ml}$. Bremner (1966) has noted values of up to $8 \mu \mathrm{g} \mathrm{Fe} / \mathrm{ml}$ in conventionally reared calves within a few weeks of birth, but these had fallen to about $4 \mu \mathrm{g} \mathrm{Fe} / \mathrm{ml}$ by the time the calves were a few months old. Kolb (1963) has reported that values are higher in calves than in adult cattle. The transferrin in the plasma of the $\mathrm{Fe}$-deficient calves in the present study was only $2 \%$ saturated. 
Another notable feature of the haematological picture in veal calves is that there is frequently no hypochromia of the erythrocytes, although the calves are suffering from what would appear to be an uncomplicated Fe-deficiency anaemia. Blaxter et al. (r957) and Eeckhout et al. (1969) have reported previously that in Fe-deficient calves the anaemia is of a microcytic, normochromic nature, although Roy et al. (1964) have suggested that when the calves become severely anaemic, hypochromia develops. Unfortunately, it is not clear what constitutes 'normal' corpuscular Hb concentrations in calves and some of the control calves used for comparisons have themselves been partly anaemic. In most published reports there has been a tendency for mean corpuscular $\mathrm{Hb}$ concentrations to be less (although not necessarily statistically different) for calves receiving no Fe supplement and for these values to diminish as the animals grow.

The main aim of this work was to gain some information on the relative availabilities of different $\mathrm{Fe}$ compounds to calves. As the effectiveness of any therapeutic $\mathrm{Fe}$ compounds must be related eventually to their ability to prevent the development of anaemia, the comparison of the $\mathrm{Fe}$ sources was based on an examination of the haematological status of the calves. There have been several reports on differences in the availability of $\mathrm{Fe}$ in the compounds examined here to rats and to man (e.g. Brise \& Hallberg, I962; Turnbull, Cleton \& Finch, I962; Hopping \& Ruliffson, 1963), but no information has been produced on their relative availabilities to calves. Indeed, very little is known of the relative availabilities of any $\mathrm{Fe}$ compounds to calves. It has been shown that there are no significant differences in the availability of ${ }^{59} \mathrm{Fe}$-labelled $\mathrm{FeSO}_{4}, \mathrm{FeCl}_{3}$ and $\mathrm{FeCO}_{3}$, as measured by tissue deposition of ${ }^{59} \mathrm{Fe}$, although measurements of ${ }^{59} \mathrm{Fe}$ in serum implied that some differences may occur between $\mathrm{FeSO}_{4}$ and $\mathrm{FeCO}_{3}$; it was found that the $\mathrm{Fe}$ in $\mathrm{Fe}_{2} \mathrm{O}_{3}$ was significantly less available than these other sources (Ammerman, Wing, Dunavant, Robertson, Feaster \& Arrington, 1967). These differences between soluble and insoluble Fe salts were also found in the present study, where $\mathrm{FeSO}_{4}$, ferric citrate and $\mathrm{Fe}-\mathrm{EDTA}$ were more available than was iron-phytate. The differences were found only after the calves had been on experiment for several weeks and were evident in the different $\mathrm{Hb}$ concentrations and $\mathrm{PCV}$ values of the calves.

The calves given the soluble $\mathrm{Fe}$ salts were improving in haematological status towards the end of the experiment and in all probability if the animals had been maintained until normal slaughter weight their final $\mathrm{Hb}$ concentrations would have been greater than the mean recorded value of $88 \mathrm{~g} / \mathrm{l}$. Thus, although a dietary intake of $40 \mu \mathrm{g} \mathrm{Fe} / \mathrm{g} \mathrm{DM}$ is not sufficient to prevent a rapid fall in $\mathrm{Hb}$ concentration in the early stages of growth (to a mean value of $79 \mathrm{~g} / \mathrm{l}$ ), nevertheless, in the long term it does prevent the occurrence of all but a very mild anaemic state. This level of $\mathrm{Fe}$ supplementation is higher than we believe is normally used by manufacturers of milk substitutes. The calves given iron phytate as Fe source were suffering from a moderate anaemia at the end of the experiment, with a mean $\mathrm{Hb}$ concentration of $7^{2} \mathrm{~g} / \mathrm{l}$ and with no signs of a significant upward trend.

Leslie $\&$ Kaldor (1971 $a, b$ ) have demonstrated that the storage (non-haem) $\mathrm{Fe}$ in the liver and other organs of neonatal rats makes only a small contribution to the 
animals' Fe requirements for $\mathrm{Hb}$ synthesis and that much of this $\mathrm{Fe}$ has been utilized by the time an animal has doubled its birth weight. It seems reasonable, therefore, to assume that in the latter part at least of the present experiment the main Fe source for haemoglobin synthesis was of dietary origin. By comparison of Fe intake with the increase in circulating $\mathrm{Fe}$ over that period it is possible, therefore, to obtain a rough estimate of the availability of the dietary Fe. Dalton \& Fisher (196r) showed that the blood volume of young calves up to a few weeks old $(29-38 \mathrm{~kg})$ was $110 \pm 20 \mathrm{ml} / \mathrm{kg}$ body-weight compared with $63 \pm 8 \cdot 3 \mathrm{~m} 1 / \mathrm{kg}$ body-weight for adult cows and heifers (weighing 200-600 kg). If the mean of these values is arbitrarily taken to represent the blood volume/kg body-weight of the veal calves in the 6-I I week period, and the $\mathrm{Fe}$ concentration of haemoglobin to be $3.4 \mathrm{~g} / \mathrm{l}$, then the amount of circulating $\mathrm{Fe}(\mathrm{mg})$ is given by:

$$
\frac{\text { body-weight }(\mathrm{kg}) \times 87 \times \mathrm{Hb} \text { concentration }(\mathrm{g} / \mathrm{l}) \times 3 \cdot 4}{\text { IO }} \text {. }
$$

The $\% \mathrm{Fe}$ utilization is then calculated to be 72,43 and $33 \%$ for the control calves and those given soluble and insoluble $\mathrm{Fe}$ salts respectively. These estimates are necessarily approximate, but they do agree reasonably well with those of Matrone et al. (1957) who reported $60 \%$ utilization of $\mathrm{Fe}$ by milk-fed calves given $3 \circ \mathrm{mg} \mathrm{Fe} / \mathrm{d}$ (as $\mathrm{FeCl}_{3}$ ) and $30 \%$ utilization by calves given $60 \mathrm{mg} \mathrm{Fe} / \mathrm{d}$. It has been noted in other species that the suckling animal is able to absorb a very high proportion of dietary $\mathrm{Fc}$. Tarvydas, Jordan \& Morgan (1968) reported, for example, that virtually all ingested Fe in milk or $\mathrm{NaCl}$ solution is retained by the suckling rabbit.

Fe supplementation had little effect on the concentration of $\mathrm{Fe}$ in any of the tissues analysed. Liver $\mathrm{Fe}$ concentrations were similar to those recorded by Roy et al. (1964) and Eeckhout et al. (1969) but less than those reported by Blaxter et al. (1957) (I 8 $\mu \mathrm{g} / \mathrm{g}$ DM for $\mathrm{Fe}$-deficient calves). As about $40 \%$ of the $\mathrm{Fe}$ in the liver was in the form of non-haem Fe, a total of about $25 \mathrm{mg} \mathrm{Fe}$ would be stored in the liver in this form. Total spleen Fe was generally around $30 \mathrm{mg}$; so Fe reserves in these organs are quite inadequate for $\mathrm{Hb}$ synthesis, considering that around $300 \mathrm{mg} \mathrm{Fe}$ would be necessary to increase blood $\mathrm{Hb}$ concentration by $\mathrm{IO} / \mathrm{g}$. Concentrations of $\mathrm{Fe}$ in longissimus dorsi muscle were around $\mathrm{x} 6 \mu \mathrm{g} / \mathrm{g}$ DM and it has been shown that much of this $\mathrm{Fe}$ is present in the form of myoglobin and $\mathrm{Hb}$ (MacDougall, Bremner \& Dalgarno, to be published).

It is not customary for the milk substitutes used in veal production to be supplemented with additional $\mathrm{Cu}$. As the dietary $\mathrm{Cu}$ concentration is then frequently $<\mathrm{I} \mu \mathrm{g} / \mathrm{g}$, the calves are very dependent on $\mathrm{Cu}$ stores, mainly in the liver, to satisfy their $\mathrm{Cu}$ requirements. These reserves were so severely depleted by the end of the present experiment that the animals could reasonably be classified as being $\mathrm{Cu}$ deficient, although blood $\mathrm{Cu}$ and ceruloplasmin concentrations in most calves were not low. This is a normal progression in the development of $\mathrm{Cu}$ deficiency. Anke (I966) has also reported signs of $\mathrm{Cu}$ deficiency in intensively reared milk-fed calves

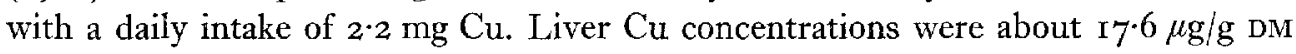
at $\mathrm{I} 4 \mathrm{O} \mathrm{d}$ of age, and he suggested that a daily intake of $7.7 \mathrm{mg} \mathrm{Cu}$ was sufficient to meet the $\mathrm{Cu}$ requirement of the calves. 
The lack of any effect of dietary supplementation with $\mathrm{Cu}$ on performance or blood $\mathrm{Hb}$ concentrations confirms the conclusions of Matrone et al. (1957) that the anaemic condition of milk-fed calves was not a consequence of $\mathrm{Cu}$ inadequacy. However, there were some effects of $\mathrm{Cu}$ supplementation on $\mathrm{Fe}$ metabolism, as there were transient increases in plasma $\mathrm{Fc}$ concentrations and decreases of $35 \%$ in liver storage $\mathrm{Fe}$ reserves in the treated calves. These changes seemed to be associated with an increase in ceruloplasmin activity, which is in accordance with the view that in $\mathrm{Cu}$ deficiency the impairment of release of $\mathrm{Fe}$ from the reticuloendothelial system and hepatic parenchymal cells (Lee, Nacht, Lukens \& Cartwright, 1968) is at least partly a consequence of the reduction in the level of plasma ceruloplasmin and, therefore, of ferroxidase activity (Osaki, Johnson \& Frieden, I966). It is noteworthy that in one calf which received the $\mathrm{Cu}$ supplement (in treatment $\mathrm{I}$ ) there was little change in the concentration of plasma $\mathrm{Fe}$, ceruloplasmin or of liver storage $\mathrm{Fe}$.

It is, perhaps, surprising that the concentrations of ceruloplasmin in the untreated calves were sufficiently low to affect the mobilization of $\mathrm{Fe}$, as it has been suggested that in pig plasma, at least, there is generally about a tenfold excess of ceruloplasmin available for $\mathrm{Fe}$ oxidation (Ragan, Nacht, Lee, Bishop \& Cartwright, I969). This may not be so in calf plasma but it has been shown (Bremner, unpublished observations) that a normal amount of ferroxidase activity is associated with the ceruloplasmin.

The most pronounced effect of $\mathrm{Cu}$ supplementation was to increase liver $\mathrm{Cu}$. Liver $\mathrm{Cu}$ concentrations were about $45^{\circ} \mu \mathrm{g} / \mathrm{g} \mathrm{DM}$, and it can be calculated that about $50 \%$ of the dietary $\mathrm{Cu}$ was retained in the liver. Such a high retention of $\mathrm{Cu}$ is of considerable interest as it is probably related to the known susceptibility of the young calf to $\mathrm{Cu}$ poisoning (Shand \& Lewis, I957).

In conclusion, this experiment has shown that there are no apparent differences in the availability of $\mathrm{FeSO}_{4}$, ferric citrate and $\mathrm{Fe}$-EDTA to veal calves but that these Fe sources are all more available than is iron-phytate. The Fe requirements of calves maintained on fat-supplemented skim milk may be different from those of calves maintained on whole milk, but a dietary intake of $40 \mathrm{\mu g} / \mathrm{g}$ soluble Fe is sufficient to prevent the development of other than a very mild anaemia. Veal calves probably suffer from $\mathrm{Cu}$ deficiency if the diet contains no supplementary $\mathrm{Cu}$ and this results in less complete utilization of liver $\mathrm{Fe}$ stores. More information is required on what constitutes optimum or 'normal' haematological status in veal calves, on their $\mathrm{Fe}$ and $\mathrm{Cu}$ requirements and on the effect of anaemia on the 'well-being' of the animals. These subjects will be considered in later papers.

The authors are grateful to $\mathrm{Mr}$ J. Mathieson for the iron analyses, Mr G. A. M. Sharman for the haematological analyses, $\mathrm{Mr}$ I. MacDonald for the statistical analysis and $\mathrm{Mr}$ R. B. Marshall for technical assistance. 


\section{REFERENCES}

Ammerman, C. B., Wing, J. M., Dunavant, B. G., Robertson, W. K., Feaster, J. P. \& Arrington, I. R. (1967). F. Anim. Sci. 26, 404 .

Anke, M. ( т 666). Arch. Tierernähr. 16, I99.

Birdsall, N. J. M., Kok, D’A. \& Wild, F. (1965). F. clin. Path. 18, 453.

Blaxter, K. L., Sharman, G. A. M. \& MacDonald, A. M. (r957). Br. F. Nutr. II, 234.

Brambell, F. W. R. (1965). Report of the Technical Committee to Enquire into the Welfare of Animals Kept under Intensive Livestock Husbandry Systems. [Cmnd 2836]. London: HM Stationery Office.

Bremner, K. C. ( 1966). Aust. F. exp. Biol. med. Sci. 44, 259.

Brise, H. \& Hallbcrg, L. (I962). Acta med. scand. r7x, Suppl. 376, p. 23 .

Dalton, R. G. \& Fisher, E. W. (1961). Br. vet. F. Ix7, I I5.

Drysdale, J. W. \& Ramsay, W. N. M. (1965). Biochem. 7. 95, 282.

Eeckhout, W., Casteels, M. \& Buysse, F. (1 969). Annls Zootech. 18, 249.

Holman, H. H. (1956). Br. vet. J. 112, 91.

Hopping, J. M. \& Ruliffson, W. S. (1963). Am. J. Physiol. 205, 885.

Houchin, O. B. (1958). Clin. Chem. 4, 519.

Kolb, E. (1963). Adv. vet. Sci. 8, 49.

Lanz, H. (1956). Schweizer Arch. Tierheilk. 98, I 53-

Lee, G. R., Nacht, S., Lukens, J. N. \& Cartwright, G. E. (1968). F. cinn. Invest. 47, 2058.

Leslie, A. J. \& Kaldor, I. (I97 I a). Am. Y. Physiol. 220, 1000.

I.reslie, A. J. \& Kaldor, I. (197 b). Br. F. Nutr. 26, 469 .

Matrone, G., Conley, C., Wise, G. H. \& Waugh, R. K. (1957). \%. Dairy Sci. 40, 143\%.

Osaki, S., Johnson, D. A. \& Frieden, E. (1966). F. biol. Chem. 241, 2746.

Owen, F. G., Voelker, H. H., Jacobson, N. L. \& Allen, R. S. (1955). J. Dairy Sci. 38, 891.

Ragan, I. A., Nacht, S., Lee, G. R., Bishop, C. R. \& Cartwright, G. E. (r969). Am. I. Physiol. 2x7, 320.

Rice, E. W. (1962). Analyt. Biochem. 3, 452 .

Roy, J. H. B., Gaston, H. J., Shillam, K. W. G., Thompsor, S. Y., Stobo, I. J. F. \& Greatorex, J. C. (1964). Br. \%. Nutr. ז8, 467.

Shand, A. \& Lewis, G. (1957). Vet. Rec. 69, 618.

Tarvydas, H., Jordan, S. M. \& Morgan, E. H. (1968). Br. F. Nutr. 22, 565 .

Turnbull, A., Cleton, F. \& Finch, C. A. (1962). F. clin. Invest. 41, 1897.

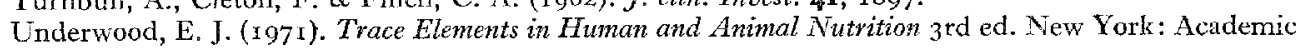
Press.

Waish, R. J., Kaldor, I., Brading, I. \& George, E. P. (1955). Australas. Ann. Med. 4, z7z.

Wing, J. M., Jacobson, N. L. \& Allen, R. S. (1955). Y. Dairy Sci. 38, 1006.

Young, D. S. \& Ilicks, J. M. (r g65). F. clin. Path. 18, 98 . 